\author{
Grażyna Zając \\ http://orcid.org/0000-0001-7547-7135 \\ Uniwersytet Jagielloński \\ grazyna.zajac@uj.edu.pl \\ DOI: $10.35765 /$ pk.2021.3201.08
}

\title{
Świat anatolijskich Ormian w opowiadaniach Hagopa Mintzuriego
}

\section{STRESZCZENIE}

Hagop Mintzuri (1886-1978) to nowelista ormiański z Turcji, urodzony w wiosce Armudan we wschodniej Anatolii. Podczas pogromu Ormian w 1915 r. przebywał w Stambule, co uratowało mu życie. W masakrze zginęła cała jego rodzina - żona i czworo małych dzieci. Zaczął publikować swoje opowiadania dopiero w drugiej połowie XX w. Choć znaczną część życia spędził w Stambule, w opowiadaniach pisał głównie o wschodnioanatolijskiej prowincji, którą zapamiętał z dzieciństwa i młodości. Mıntzuri jest klasyfikowany jako przedstawiciel nurtu wiejskiego w literaturze zachodnioormiańskiej. Pisał w języku ormiańskim, a jego książki tłumaczone są przez tureckich Ormian na język turecki i cieszą się dużą popularnością.

W artykule omawia się tematykę opowiadań Mintzuriego ze zbioru Skąd przybywasz, żurawiu, które są bezcennym źródłem wiedzy o nieistniejącym już świecie prastarego chrześcijańskiego narodu w Azji Mniejszej - anatolijskich Ormian. Świat ten odszedł na zawsze wraz z okrutną deportacją Ormian. Dzięki opowieściom Mıntzuriego, napisanym bardzo szczerym, bezpretensjonalnym językiem, poznajemy codzienne życie, troski, radości, a przede wszystkim ciężką pracę mieszkańców ormiańskich wsi wschodniej Turcji przed I wojną światową. Główne tematy w tych opowiadaniach to: dziecko, sytuacja kobiety, ciężka praca rolnika, tradycje, narodziny, śmierć, sezonowa praca w Stambule.

We wnioskach końcowych uzasadnia się tezę o wielkiej roli wątków autobiograficznych w literaturze. Sprawiają one, że dzieło literackie staje się paradokumentem epoki. Zachowując urodę literatury i fikcji, dostarcza także wiedzy o realiach.

SŁOWA KLUCZE: Ormianie, Turcja, Hagop Mıntzuri, Agop Demirdżian, nowelistyka ormiańska 


\section{ABSTRACT}

The World of the Anatolian Armenians in the Short Stories of Hagop Mintzuri

Hagop Mintzuri (1886-1978) is an Armenian short story writer from Turkey, who was born in the village of Armudan in Eastern Anatolia. During the Armenian genocide in 1915 he was staying in Istanbul, and this saved his life. His entire family - his wife and four little children - were killed in the massacre. He began to publish his short stories only in the second half of the 20th century. Even though he lived a considerable part of his life in Istanbul, in his short stories he discussed mainly the east Anatolian province which he remembered from the days of his childhood and youth. Mintzuri is classified as a representative of the peasant writing in Western Armenian literature. He wrote in the Armenian language, and his books, which enjoy considerable popularity, are translated by the Turkish Armenians into Turkish.

The article discusses the subject matter of Mintzuri's stories from the collection Turna Nereden Gelirsin (Crane, Whence Do You Come), which constitute an invaluable source of information about the world of the ancient Christian people in Asia Minor - the world of the Anatolian Armenians which no longer exists. This world disappeared forever due to the cruel deportation of the Armenians. Owing to the frank, unaffected prose of Mintzuri's stories, we may experience the day-to-day activities, concerns, delights, and above all the toil of the inhabitants of the Armenian villages of Eastern Turkey before the First World War. The main themes which are explored in these stories have to do with children, the situation of women, the difficult labours of a farmer, traditions, birth and death, seasonal work in Istanbul.

The conclusions justify the thesis about the significant role of the autobiographical themes in literature. The latter make a work of literature a paradocument of its age. Preserving the charm of literature and fiction, it also provides an insight into the realia.

\section{KEYWORD S : Armenians, Turkey, Hagop Mıntzuri, Agop Demirgian, Armenian short story}


Sędzio żywych i umarłych (...)

Wejrzyj na lud zamieszkujący tę ziemię, który od tak dawna trwa ufnie przy Tobie i który, choć doświadczył wielkich cierpień, zawsze dochowywał Ci wierności.

(Jan Paweł II, Erywań, 2001)

\section{Ormianie w Anatolii}

Ormianie - naród o wielowiekowej historii, której początki sięgają czasów starożytnych, jeden z pierwszych chrześcijańskich narodów świata w wyniku wielu tragicznych wydarzeń żyją dziś w rozproszeniu, w licznych diasporach rozrzuconych po świecie. Bardzo bolesny dla Ormian jest fakt, że znacząca większość narodu mieszka poza granicami kraju. Tym krajem ojczystym, ale dziś bardzo okrojonym, jest Republika Armenii, była republika radziecka. Rzeczywista ojczyzna Ormian była jednak znacznie rozleglejsza. Rozpościerała się daleko na zachód od dzisiejszej Armenii, bowiem dawne terytoria ormiańskie obejmowały całą Wyżynę Armeńską od pasma Małego Kaukazu na północnym wschodzie po środkową Anatolię, a w okresach największej świetności (Królestwo Cylicyjskie, XII-XIV w.) aż po Cylicję i wybrzeża Morza Śródziemnego. Kres ormiańskiej państwowości w Anatolii położyli Turcy. Ormianie wciąż jednak żyli w Azji Mniejszej i aż do I wojny światowej w niektórych regionach wschodniej Turcji stanowili znaczący odsetek mieszkańców. Znani z wielkiej pracowitości, zamieniali nieurodzajne, kamieniste zbocza górskie w pola i winnice, rozwijali hodowlę, rzemiosło i handel. Na ziemiach wschodniej Anatolii od wieków zamieszkałych przez Ormian znajdują się dziś takie prowincje (vilayet) Republiki Turcji, jak Ardahan, Kars, Bayburt, Erzincan, Erzurum, Van, Bitlis, Diyarbakır, Sivas i Ağrı ze świętą górą Ararat. Bardzo duże skupiska Ormian znajdowały się aż do I wojny światowej w wielkich miastach zachodniej Turcji, takich jak Stambuł i Izmir. I to w tych miastach mieli oni najlepsze możliwości rozwoju duchowego i edukacji, natomiast ormiańska „prowincja”, czyli wschodnia Anatolia pozostawała biedna i zaniedbana. Tę dwoistość ormiańskiej kondycji wyraźnie uchwycił - być może nieświadomie - pisarz, który jest przedmiotem tej pracy, Hagop Mintzuri.

W wielonarodowym państwie osmańskim każdy poddany bez względu na wyznanie miał szansę zdobycia wykształcenia i zrobienia kariery, także tej państwowej. Mniejszości religijne (millet) miały prawo do wyznawania swojej religii, posiadały własny system szkolnictwa. Dotyczyło to przede wszystkim Żydów, Ormian i Greków, a Ormianie wyróżniali się w tej 
grupie swoistą „elitarnością”, którą historyk Tomasz Wituch opisuje tymi słowami:

Do połowy XIX wieku nie słychać było o większych konfliktach ormiańsko-osmańskich. Przeciwnie, ten inteligentny, kupiecko-rzemieślniczy lud zdołał sobie w państwie sułtańskim wyrobić świetną pozycję i miano „wiernego ludu” (millet-i sadıka) sułtanów. Poza wilajetami wschodnimi, tj. Armenią właściwą, gdzie mieszkała część Ormian i gdzie stanowili ludność rolniczą, w reszcie państwa byli rozproszeni. Stanowili przeważnie ludność miejską. W ich rękach była większość rzemiosła osmańskiego, a w handlu skutecznie rywalizowali z Grekami. Do połowy XIX w. przenikali bez większych przeszkód do rozmaitych szczebli w administracji sułtańskiej. Finanse, kontakty z Europejczykami, w pewnej mierze oświata, wolne zawody - głównie lekarze - oto sfery ich działalności. W przeciwieństwie do Greków, zawsze podejrzanych o skłonności do irredenty na rzecz idei helleńskiej, Ormianie byli przez długi czas dopuszczani do wszystkich, czasem bardzo lukratywnych stanowisk (1980, s. 61).

Pierwsza połowa XIX w. była dla tureckich Ormian czasem wyjątkowego rozkwitu, przede wszystkim w dziedzinie literatury, szeroko pojętej kultury (w tym m.in. teatr i prasa), kontaktów kulturalnych, naukowych i zawodowych z Europą. Szczególny postęp zaznaczył się na polu ormiańskiej edukacji. Staraniem zagranicznych fundacji i lokalnej ormiańskiej elity powstawały szkoły (również i żeńskie) reprezentujące taki poziom, o jakim Turcy mogli tylko marzyć ${ }^{1}$. Wyjątkowe zasługi w dziele kształcenia ormiańskiej młodzieży w Turcji położył katolicki zakon ojców mechitarystów założony przez tureckiego Ormianina, Mechitara ${ }^{2}$. W utworach Hagopa Mintzuriego, zwłaszcza w jego autobiografii, można znaleźć wzmianki o kilku szkołach, w których sam się uczył.

Pokojowe wspólistnienie Turków i Ormian, trafnie określane przez Witucha terminem „symbioza” (1980, s. 60-61), zaczęło się psuć w pierwszej połowie XIX w., choć w tym okresie nie dochodziło jeszcze do większych ataków agresji. Jak pisze Grzegorz Kucharczyk (2004):

dla dobrego funkcjonowania milletu konieczne było istnienie dwóch przesłanek: silnego państwa tureckiego oraz braku większych aspiracji politycznych wśród nie-muzułmańskich społeczności. Już na początku XIX wieku stało się zupełnie jasne, że warunki te nie są do spełnienia (s. 21).

1 O szkołach nietureckich w państwie osmańskim: Zając, 2013, s. 174-177 i 231-246; Zając, 2016.

2 O izmirskim liceum ojców mechitarystów oczami muzułmańskiego ucznia: Zając, 2020. 
Jako główne przyczyny rosnącej wrogości między Turkami i Ormianami wskazać można m.in.: upadek potęgi imperium skutkujący frustracją Turków i wybijaniem się na niepodległość podbitych narodów bałkańskich; wzrost świadomości narodowej Ormian; powstanie świadomości narodowej Turków (świadomości tureckiej w miejsce kosmopolitycznej osmańskiej); rozwój nacjonalizmów po obu stronach; wojny rosyjsko-tureckie, w których tureccy Ormianie stawali po stronie Rosji; wspieranie przez Rosję ormiańskich ambicji niepodległościowych. Jak pisze Bernard Lewis (1972):

Dla Turków ruch ormiański był śmiertelnym niebezpieczeństwem, bardziej jeszcze niż inne ruchy niepodległościowe. Ze zdobytych przez siebie krajów Serbów, Bułgarów, Albańczyków czy Greków mogli oni - aczkolwiek niechętnie - ustąpić, opuścić te odległe prowincje i przesunąć granice imperium bliżej rdzenia ojczyzny. Jednakże Ormianie, których siedziby rozciaggały się przez Turcję azjatycką od granicy Kaukazu po wybrzeże śródziemnomorskie, znajdowali się w samym sercu tureckiej ojczyzny, a wyrzeczenie się tych ziem oznaczałoby nie okrojenie, ale rozpad państwa tureckiego (s. 417).

I w takim właśnie okresie, kiedy narody zamieszkujące Anatolię wciąż żyły obok siebie w „symbiozie”, ale z różnych miejsc Turcji, szczególnie z miast, dochodziły już wiadomości o aktach agresji wobec ludności ormiańskiej, przyszedł na świat Hagop Mintzuri - świadek historii, kronikarz utraconego bezpowrotnie świata. $W$ jego utworach nie ma nienawiści, widać raczej pogodzenie się z losem. Zarówno w rodzinnej wiosce, jak i w Stambule przyszło mu żyć w wielonarodowym otoczeniu, mając za sąsiadów Turków, Kurdów, alewitów, Greków. Wszyscy oni byli tak samo biedni jak on, prowadzili podobnie skromne życie, tak samo bardzo ciężko pracowali, a kiedy była potrzeba, pomagali sobie nawzajem. Nie zaprzątali sobie głowy sprawami, które zajmowały umysły możnych tego świata: polityką, nienawiścią, zacietrzewieniem. I taki właśnie obraz Anatolii uwiecznił Mintzuri w swoich utworach.

\section{Hagop Mıntzuri - próba życiorysu}

Urodziłem się we wsi Armudan [obecnie Armutlu - G.Z.]. Była to wioska licząca siedemdziesiąt domów, należąca do wilajetu Erzincan. Moja data urodzenia to 16 października 1886, czwartek. Są dwie wioski Armudan. Wielki Armudan, oddalony od naszego o dziesięć minut drogi, liczył trzysta domów. Ja jestem z Małego Armudanu. Znajduje się on na wprost 
łańcucha górskiego Munzur, inaczej zwanego górami Dersim, po północnej stronie Eufratu. Najbliższym miastem było Eğin [obecnie: Kemaliye, orm. Lłઈ - G.Z.]. Nasz bogaty i barwny folklor wywodził się właśnie z Eğin. W tych stronach były tylko góry i doliny; równin nie było tam wcale. Wszystko to żyje we mnie z najdrobniejszymi szczegółami krajobrazu; z wioskami, ich mieszkańcami, ubiorami i mentalnością (Mıntzuri, 2002b, s. 142).

Takimi słowami przedstawia siebie skromny ormiański pisarz Hagop Mintzuri ${ }^{3}$, którego data urodzenia tak bardzo kojarzy nam się z dumą naszego narodu, Janem Pawłem II. Urodził się w niezamożnej wiejskiej rodzinie. Skończył 5-letnią szkołę ormiańską, z której wyniósł wiedzę niespotykaną wśród muzułmańskich rówieśników, gdyż poziom szkół chrześcijańskich był o wiele wyższy niż tradycyjnych szkół muzułmańskich, stawiających za główny cel nabycie umiejętności czytania Koranu po arabsku. W każdej ormiańskiej szkole początkowej, nawet w najmniejszej miejscowości, od trzeciej klasy obowiązywała nauka francuskiego. Oprócz podstawowych przedmiotów, jak nauka czytania i pisania po ormiańsku, arytmetyka, religia, uczniowie poznawali także sztukę pisania dokumentów urzędowych i handlowych w języku osmańskim, co później bardzo przydawało się w życiu zawodowym. Jak Mintzuri podaje w swoich wspomnieniach (2002a, s. 11), autorem podręczników języka osmańskiego dla ormiańskich dzieci był zasłużony nauczyciel i pedagog Mihran Apikian. A w napisanym przez siebie biogramie dołączonym do tomu opowiadań (2002b, s. 142) pisarz podkreśla dobrą organizację ormiańskiego szkolnictwa: nauka i podręczniki były bezpłatne, szkoły utrzymywano z dochodów, które płynęły z należących do Kościoła majątków rolnych.

W wieku jedenastu lat Hagop wyjechał do Stambułu, gdzie już od kilku lat pracowała większość jego krewnych, w tym i ojciec. Było to powszechne zjawisko na ormiańskiej prowincji: praca w polu spoczywała na barkach najstarszych mężczyzn, kobiet i dzieci, a młodsi mężczyźni wyjeżdżali do odległych miast, skąd przysyłali do domów zarobione pieniądze. Hagop miał odtąd ciężko pracować w rodzinnej piekarni, ale równocześnie kontynuować naukę. Po latach tak to opisał: „Kiedy przybyłem tutaj jeszcze jako dziecko, to i chodziłem do szkoły, i dorastałem

3 W niniejszej pracy stosuje się turecki zapis imienia i przybranego nazwiska pisarza, widniejący na okładkach wszystkich jego książek opublikowanych w języku tureckim: Hagop Mintzuri (literę „1” czyta się jak „y”). Według Gizem A. Genç (2013) nazwisko to autor przybrał od nazwy rzeki Munzur płynącej przez Wyżynę Armeńską, ale nazwę Munzur nosi też łańcuch górski (Munzur Dağları), który kilkakrotnie wspominany jest w opowiadaniach Mıntzuriego jako jeden z najbardziej charakterystycznych elementów krajobrazu rodzinnych stron. Opracowania na temat pisarza sporadycznie posługują się też jego nazwiskiem rodowym Demirdżijan (tur. Demirciyan). 
w piekarni wśród chlebów. Wstawałem o piątej, szóstej, a wracałem do domu o dziewiątej, dziesiątej. Niedziel też nie miałem” (Mintzuri, 2002a, s. 153). Chłopiec musiał rano załadować gorące jeszcze pieczywo do koszy zarzuconych na koński grzbiet i w kilku turach dostarczyć setki bochenków do stałych klientów rozrzuconych po całej dzielnicy. Potem mógł biec do szkoły, a po nauce wracał do pracy przy wieczornym wypieku.

Podczas pobytu w Stambule Hagop uczył się kolejno w trzech szkołach. Pierwszą była ekskluzywna francuska placówka należąca do sieci École Française, z francuskim językiem wykładowym. Hagopa przyjęto od razu do trzeciej klasy. Po trudnym pierwszym miesiącu oswoił się z nauką w języku francuskim i skończył tę klasę jako prymus, podobnie po dwóch latach otrzymał dyplom ukończenia szkoły z pierwszą lokatą. Tytuł prymusa odebrał trzem koleżankom, do tej pory najlepszym uczennicom. Poniższy fragment wspomnień wyraziście pokazuje poziom nauki w ormiańskich wiejskich szkołach początkowych na dalekiej prowincji:

Lekcje były łatwe. Większość tego wszystkiego już umiałem i tylko sobie powtarzałem. Na koniec roku okazałem się najlepszy! Najemi, córka pułkownika wojskowego, okulisty Dikrana Adżemiana, która zawsze była prymuską, teraz miała drugie miejsce, a Selma i Semra, córki Sadettina Beja, tłumacza przy ministrze spraw zagranicznych, teraz zajęły trzecie i czwarte miejsce. Te trzy dziewczynki miały w domu francuskie guwernantki, podczas gdy ja przyszedłem do tej szkoły z dalekiej prowincji Erzincan, z małej wioski, z pastwisk nad Eufratem, z otaczających je gór; przyszedłem tu z tym, czego się tam nauczyłem (Mintzuri, 2002a, s. 51).

Przez kolejne dwa lata Hagop uczył się w klasycznym ormiańskim liceum męskim Getronagan w dzielnicy Galata, a kiedy piekarnia $z$ powodu problemów finansowych musiała szukać klientów w innej dzielnicy, przeniesiono się daleko na północne krańce miasta. Oznaczało to kolejną zmianę szkoły. Do Hagopa znów uśmiechnęło się szczęście: przyjęto go do ekskluzywnego koledżu działającego w tej podmiejskiej wówczas dzielnicy Bebek. Ta amerykańska szkoła męska Robert College ${ }^{4}$ cieszyła się opinią jednego z najlepszych liceów w Stambule, nastawiona była na działalność wychowawczą i edukacyjną wśród chrześcijańskiej

4 Założona w 1840 r. przez amerykańskich filantropów Ch. Roberta i C. Hamlina szkoła początkowo była zakładem szkolno-wychowawczym dla zaniedbanej młodzieży chrześcijańskiej, przede wszystkim ormiańskiej, ale z biegiem lat zmieniała swój charakter. Od roku 1863 działała jako liceum, a poziomem nauczania przyciągała młodzież z wyższych warstw społecznych. Działa do dziś jako ekskluzywne prywatne liceum, a na bazie tej szkoły od lat 50 . XX w. rozwijano szkołę wyższą, która od 1971 r. nosi nazwę Boğaziçi Üniversitesi (Uniwersytet Bosforski) i obecnie należy do najlepszych tureckich uczelni. 
młodzieży, a niezamożnym, zdolnym uczniom umożliwiała bezpłatną naukę. Choć placówka ta miała obowiązkowy internat, Hagop został z niego zwolniony, gdyż wciąż musiał pracować w piekarni ojca. Pięcioletnia nauka w Robert College znacząco poszerzyła wiedzę przyszłego pisarza, czyniąc z niego wyjątkowego jak na osmańskie warunki erudytę.

W roku 1907 Mintzuri powrócił do rodzinnej wsi z dyplomem koledżu uprawniającym do podjęcia pracy w szkole. Ożenił się z wiejską dziewczyną, którą znał od najmłodszych lat, i zaczął pracę w tej samej szkole, którą kiedyś skończył. Zgodnie z miejscową tradycją każdego roku 15 października zaraz po zbiorach winogron otwierał szkołę i prowadził zajęcia do 15 kwietnia. Potem zamykał ją na pół roku i stawał się rolnikiem, ciężko pracując z żoną na rodzinnym polu. Voğıda urodziła mu troje dzieci i spodziewała się czwartego. Chcieli mieć jeszcze co najmniej czworo, bo taka była tradycja w ich rodzinach. To szczęśliwe życie zostało przerwane przez największą tragedię w historii narodu...

Latem 1914 r. Mintzuri postanowił pojechać do Stambułu, by u znanego ormiańskiego chirurga Undżujana poddać się operacji usunięcia migdałków.

Powiedziałem o tym Voğıdzie, a wieczorem dziadkowi i mamie. „Nie zostanę tam na dłużej. Posiedzę ze dwa dni i wrócę”, mówiłem. Nie chcieli mnie puścić. (...) Upierałem się: „Wszystko razem z podróżą nie potrwa więcej jak 20-25 dni. Nawet nie będę żegnał się z domem, tak szybko wrócę”. Czyż mogłem przypuszczać, co się wydarzy? Czy mogłem przewidzieć, że nie wrócę i że już nigdy ich nie zobaczę? Żegnali mnie we łzach. Zmartwiło mnie to i nawet przeszło mi przez myśl, żeby nigdzie nie jechać. Jednak zostawiłem ich i wyszedłem z domu (Mintzuri, 2002a, s. 126).

W kilku miejscach swoich wspomnień i biogramów Mintzuri pisze: „Stambuł uratował mi życie”. Tak, wyjazd do Stambułu w sierpniu 1914 r. ocalił go od śmierci, ale to dalsze życie już nigdy nie było szczęśliwe. Dzień po operacji miał wsiąść na parostatek i wrócić do domu. Przypadek sprawił, że spóźnił się 25 minut, a następny statek miał być za dwa tygodnie. Wkrótce Turcja ogłosiła mobilizację, która i jego objęła. Ich rodzinna piekarnia została przyłączona do armii, a piekarze przeszli pod rozkazy wojskowe. W pierwszym liście z domu otrzymał radosną nowinę, że na świat przyszło jego czwarte dziecko. Syn urodził się w dniu święta Haczwerats (Święto Podniesienia Krzyża) i na pamiątkę tego dnia otrzymał imię Haczo.

W kwietniu 1915 roku rozpoczęto deportację Ormian anatolijskich mieszkających w Stambule, ale ja byłem żołnierzem. W maju nie dostałem listu z domu. Wysłałem dwa telegramy z opłaconą odpowiedzią, ale nie 
odpisano. Dopiero na trzeci dostałem odpowiedź: „Nie mieszkają tutaj, miejsce przebywania nieznane”. Mój dziadek Melkon miał osiemdziesiąt osiem lat, moja matka Nanik - pięćdziesiąt pięć. Nurhan miała sześć lat, Maranik cztery, Arahit dwa, a Haczo - dziewięć miesięcy. Moja żona Voğıda miała dwadzieścia dziewięć lat. Jak oni szli? Przecież mój dziadek nie był w stanie dojść nawet do studni (...). Po jakimś czasie do Stambułu przyjechał Kurt Temer. Odkąd pamiętam, najmował się do pracy w polu u moich krewnych. Mówił biegle po ormiańsku. Powiedział nam, że deportacja nastąpiła 4 czerwca i że ludzie opuszczając swoje domy całowali drzwi tak, jak się całuje kościelne wrota.

Jeśli ktoś z waszych bliskich umrze, czy wy nie umieracie razem z nim? Czy potraficie dalej pracować? Czy jesteście w stanie funkcjonować? Byłem żołnierzem pod rozkazami. Nie mogłem nawet usiąść. Do wieczora trzeba było pracować. Musiałem liczyć chleby ładowane na wojskowe wozy i nadążać za wołami. A ile się nachodziłem między Üsküdarem a koszarami Selimiye, między piekarnią na przystani Kavak a naszą piekarnią! Nawet nie próbuj myśleć o swoich bliskich! Wyrzuć ich z głowy! Nie zastanawiaj się, co jedli i gdzie kładli się do snu! Nie myśl! To, że nie umarłem i dożyłem dzisiejszego dnia, zawdzięczam dwudziestu pięciu minutom spóźnienia. Tak, dwudziestu pięciu minutom. Przybiegłem zdyszany na przystań w Galacie, ale statku już nie było (Mintzuri, 2002a, s. 133-134).

Te słowa Mintzuri zapisał rok przed śmiercią, we wrześniu 1977 r., kiedy kończył pracę nad wspomnieniami. Tylko tyle i aż tyle napisał o swojej tragedii. O dalszych latach jego życia wiadomo bardzo niewiele, bo wszystkie teksty, które o sobie napisał, łącznie ze wspomnieniami (2002a), sprawiają wrażenie, jakby jego życie skończyło się w 1915 r., a potem nie było już nic. Wiadomo tylko, że kilka lat po tragedii ożenił się ponownie i doczekał się trójki dzieci, że do końca życia mieszkał w Stambule, pracując na stanowiskach zupełnie nieodpowiadających jego wykształceniu i kompetencjom, m.in. jako recepcjonista w hotelu, sprzedawca węgla, kościelny w Surp Harutiun, a rodzinnych stron nie odwiedził nigdy. Poza kilkoma opowiadaniami, które wyszły w ormiańskiej prasie między 1906 a 1914 r., przez długie lata nic nie publikował. Trzy tomy opowiadań wydał w latach 1958, 1966 i 1974, a czwarty został opublikowany po jego śmierci. Jak sam wyliczył w przedmowie do ostatniego wydanego przed śmiercią tomu (Mintzuri, 2012, s. 267), na jego dorobek składa się ponad trzysta krótkich form pisanych prozą, wśród których - oprócz klasycznych opowiadań - znajdują się pisane do ormiańskiej prasy felietony o książkach, pisarzach, wydarzeniach kulturalnych i codziennych sprawach.

Bardzo lapidarnie i obrazowo scharakteryzował kwestię świata przedstawionego w utworach Mintzuriego Florian Riedler: „Dom Hagopa 
Demirdżiana i jego wioska Armudan przestały istnieć, zanim stały się centralnym miejscem jego utworów" (2009, s. 8). Znamienny jest fakt, że wszystkie opowiadania Mintzuriego dotyczą świata sprzed tragedii. Bez względu na to, czy akcja toczy się w Stambule, czy we wschodniej Anatolii, Mintzuri opisuje ludzi, których już nie ma. Nie pisze o żywych. On ożywia umarłych...

\section{Ojczyzna utracona albo „skąd przybywasz, żurawiu?”...}

Obraz życia Ormian anatolijskich w świetle opowiadań Hagopa Mintzuriego przedstawiony jest w niniejszym rozdziale na podstawie zbioru Turna Nereden Gelirsin (polskie tłumaczenie tytułu: „Skąd przybywasz, żurawiu”; oryginał orm. Grung usdi gukas). Był to trzeci (i ostatni wydany za życia) zbiór opowiadań Mıntzuriego. Tytuł książki pochodzi z popularnej ormiańskiej piosenki wyrażającej tęsknotę za ojczyzną, do której nie można wrócićs

Akcja większości opowiadań toczy się na wsi wschodniej Anatolii i tylko pojedyncze utwory dotyczą Stambułu. Tematy oscylują wokół ciężkiej pracy ormiańskich wieśniaków, a głównymi bohaterami są kobiety, starsi mężczyźni i dzieci. Młodsi mężczyźni rzadko się pojawiają, co nie dziwi, biorąc pod uwagę fakt, że większość zdrowych, zdolnych do pracy Ormian wyjeżdżała do pracy w miastach. Na drugim planie spotykamy przedstawicieli innych grup narodowych, żyjących w sąsiedztwie i dzielących wspólny los z Ormianami: Turków, Kurdów, turkmeńskich alewitów. Ważne miejsce w opowiadaniach zajmują zwierzęta jako nieodzowni towarzysze mieszkańców wsi. Przedstawiane są ciepło, z dużą dozą sympatii, nieraz i humorystycznie, często też zauważamy skłonność autora do personifikacji.

Lektura opowiadań tego tomu dostarcza różnego rodzaju informacji o wiejskim życiu: o pracach polowych, obowiązkach dzieci, strukturze rodziny, pozycji kobiety, wyposażeniu domu i zagrody. Najczęściej opowiadania poświęcone są niewielkiemu wycinkowi codziennego życia i pojedynczym tematom. Są wśród tych tematów takie jak: potrawy, ubiór, wyprawa dzieci z kozami na pastwiska, praca młynarza, podróż na mule, wychowanie dzieci, żniwa, śmierć od ukąszenia żmii, obrzędy pogrzebowe, poród w polu. Natomiast opowiadanie Jesień (Mintzuri, 2012, s. 23-34) pomimo dość banalnej tematyki (prosty opis jednego dnia

5 Pierwsza zwrotka piosenki w tłumaczeniu na język polski: „Skąd przybywasz, żurawiu? Błagam cię, powiedz / Czy masz jakieś wieści z moich stron? / Nic nie mówisz i odlatujesz / Żurawiu, poleć tam i przynieś mi wiadomość". 
z życia rodziny) zapewnia wieloaspektową wiedzę o świecie ormiańskich mieszkańców Anatolii, w bezpretensjonalny sposób przedstawiając pracowity, listopadowy dzień pewnej rodziny. Głową domu jest Vosgehan, drugą ważną osobą jest jego żona. Mieszkają z nimi dwie synowe i pięcioro wnucząt, a synowie wypiekają chleb w Stambule. Z opisu inwentarza i dobytku można wnioskować, że rodzina jest zamożna, ale widać też, że na ten dorobek ciężko pracują wszyscy mieszkańcy domu z wyjątkiem najmłodszych dzieci. Zwraca uwagę porządek dnia i ściśle przestrzegany podział obowiązków - w tym domu każdy wie, co do jego zadań należy i nikt nikomu o tym nie musi przypominać. Kiedy czytamy opisy kolejnych zajęć i czynności wykonywanych przez członków rodziny, przed oczami staje nam obraz trybików sprawnie działającego zegara. Odnosi się wrażenie, że również zwierzęta w tym gospodarstwie wiedzą, co do nich należy, i wykonują swoje zadania bez zbędnego poganiania.

Dzień zaczyna się o świcie. Vosgehan wchodzi do ciemnej stajni, która wraz z otwarciem wrót rozjaśnia się światłem poranka. W środku jest bardzo ciepło, choć na zewnątrz panuje chłód. Przy żłobach stoją krowy, cielaki, jałówki, pod ścianą trzy woły, które leniwie przeżuwają, zbierając siły do ciężkiej pracy. W oddzielonym deskami kącie stoją dwa osły, a całości inwentarza dopełniają kury i koguty, poruszające się swobodnie po całej stajni. Kiedy tylko gospodarz uchyla drzwi, ptactwo wypada z łoskotem na świeżo pozamiatane przez młode kobiety podwórze. Vosgehan kieruje swe kroki do najważniejszych mieszkańców stajni:

Podszedł do wołów i delikatnie dotknął kolan dwóch z nich. Przerwały przeżuwanie i podniosły się. Trzeciego nie dotknął. A on, nie ruszając się, dalej spokojnie przeżuwał.

- Ty sobie siedź, nie wstawaj. Co dzień jeden z was będzie sobie odpoczywał, żebyśmy mieli siłę orać - powiedział. - Was trzech, ja jeden, to razem nas czterech. Pole już na nas czeka. Stodołę napełnimy sianem, spichlerz pszenicą, mąką. Wszystko na naszych barkach, kochani ojczulkowie.

Odwiązał powrozy na szyjach wołów i wtedy ruszyły dostojnym krokiem w stronę wrót, mijając krowy i cielęta. Czarny cielak z poprzedniego roku odwrócił głowę i patrzył w ślad za wołami.

- Co się patrzysz? - odezwał się Vosgehan. - Jesteś jeszcze mały. Za rok jeszcze nie, ale za dwa lata ty też pójdziesz w pole tak jak one. Ciebie też zaprzęgnę do pługa. Ziarno w żłobie ani mąka na chleb nie spadają z nieba. Trzeba pracować, żeby jeść (Mıntzuri, 2012, s. 24).

Teraz uwaga autora przenosi się na kobiety. Najpierw pojawiają się synowe. Obie mają na nogach skórzane łapcie i grube, kolorowe skarpety sięgające kolan, własnoręcznie wydziergane i ozdobione. Tego dnia 
wybierają się z motykami kopać w polu. Zanim tam pójdą, mają przygotować osła, którego zabierze do pracy ich teść. Starsza synowa, szczupła, o pociąłej twarzy, wyprowadza osła ze stajni, zarzuca mu na grzbiet siodło, wprawnymi ruchami zapina podogonie i popręg. Ale do załadowania ciężkich juków z ziarnem potrzebna jest druga osoba...

Przyszła i młodsza synowa. Średniego wzrostu, z wielkim brzuchem; to ta, która ma dzidzię w brzuchu; ta rumiana, o policzkach jak czerwone jabłka i błyszczących oczach. (...) Ona też pójdzie kopać w polu. Złapały juki z obu stron. To nie było bardzo ciężkie - każda torba ważyła z dziesięć okka $[1 \mathrm{okka}=$ ok. $1.28 \mathrm{~kg}-$ G.Z.]. Ale trzeba było to przenieść z domu do miejsca, gdzie stał osioł, podnieść i przerzucić ponad siodłem. Zebrały w sobie wszystkie siły i zarzuciły. Jedna torba zawisła po jednej stronie, druga po drugiej stronie siodła. Osioł ani nie drgnął. Pochylił głowę i rozmyślał. Przecież i tak wiedział, że to będzie jego robota (2012, s. 25).

Młodsza synowa przynosi z domu łapcie i podaje teściowi. Kiedy Vosgehan je zakłada, ona już otwiera bramę. Woły same ruszają przed siebie w dobrze znanym sobie kierunku, za nimi rusza i osioł, a na końcu gospodarz. Pole znajduje się daleko za wsią. Po drodze mijają źródło, które służy wszystkim mieszkańcom wsi - ludziom i zwierzętom. O tej wczesnej porze nie ma tu jeszcze nikogo. Woda spokojnie przelewa się z jednego koryta do drugiego, a wszystkich koryt jest pięć. Jedno z nich, odseparowane ścianami z desek, przeznaczone jest wyłącznie dla kobiet. Przychodzą tutaj zaczerpnąć wodę do dzbana albo zrobić pranie.

Woły Vosgehana, przyzwyczajone do codziennego rytuału, podchodzą do koryt i długo piją, aby nasycić się na cały dzień pracy, po czym ruszają dalej w drogę. Vosgehan chce, aby i osioł skorzystał z wodopoju:

- No, dalej! Weźże, podejdź tu i napij się! - krzyknął do osła.

Nie, za nic w świecie! Nie miał zamiaru zbliżyć się do koryta i pić. W jednym z koryt majaczyły dwa straszne kształty. Nie wiedział, co to jest i bardzo się bał.

- Głupcze! To tylko twoje uszy! - zawołał Vosgehan.

O, nie! To nie były jego uszy! Swoje uszy miał na głowie! Choćby go mieli zabić, nie podejdzie do koryta! Nie napije się!

Vosgehan złapał osła za łeb i przyciągnął do koryta. Osioł odskoczył do tyłu. Vosgehan szarpnął jeszcze raz, ten ponownie odskoczył.

- Głupi ty! Patrz, woły poszły! Pewnie już są za młynem, a my wciąż tu sterczymy!

- Rób, co chcesz, a ja i tak nie będę tutaj pił.

- Nie będziesz? A to idź w czorty! - powiedział i zdzielił osła kijem po zadzie. Zabolało. 
- Ty mnie będziesz bił? A masz! - osioł wierzgnął tylnymi nogami i popędził przed siebie $\mathrm{w}$ podskokach. Jedna $\mathrm{z}$ toreb spadła mu pod brzuch, druga znalazła się na siodle. Vosgehan przestraszył się na dobre. Jeszcze trochę, a dwa worki pszenicy wysypią się na drogę!

- Prrrrr! Stój! - wołał, pędząc co sił w nogach za osłem.

Osioł pierwszy dobiegł do wołów i zatrzymał się. Za nim przybiegł ledwo żywy Vosgehan. Poprawił juki. Mało brakło, a wszystko by się wysypało (2012, s. 26-27).

W drodze do pola nasi bohaterowie mijają jeszcze jedno źródło. To, z którego rzadko ktoś korzysta, gdyż woda jest tutaj brudna i niesmaczna. W korycie zawsze stoi mętna ciecz. Woły mijają źródło z wielką obojętnością, natomiast osioł podchodzi do koryta i długo pije. Woda jest tak mętna, że nie widać w niej odbicia jego uszu, więc nie musi się niczego bać.

Kiedy docierają na pole położone na górskim zboczu, Vosgehan najpierw zdejmuje juki z osła i przemawia do niego czule, chcąc go udobruchać za nieporozumienie przy wodopoju. Obiecuje mu, że zaraz odeśle go do domu, jak tylko przybędzie tu jego wnuk.

Nie minęło kilka minut, a nadszedł Ago, chłopak młodszej synowej, tej co ma dzidzię w brzuchu. Zdjął worek z pleców, położył na ziemi, spojrzał na dziadka. Miał takie same oczy, jak jego matka. Błyszczące. I taką samą twarz, rumianą.

- Pokaż, co przyniosłeś - powiedział Vosgehan.

- A co miałbym przynieść, dziadku? Siano dla wołów, dla ciebie chleb i zupę z ajranu.

- A cebuli babcia dała?

- Zapomniała! Ale ja jej przypomniałem, że lubisz zupę jeść z cebulą i dała dwie.

Pod długimi, sięgającymi uszu wąsami Vosgehana rozciągnął się uśmiech.

- Zuch chłopak! Masz takie bystre oczy. Będziesz najmądrzejszy z moich wnuków. Dziewczyny i tak pójdą z domu. Będą rozweselać cudze domy. No, to siadaj na osła i wracaj. Po co ma tutaj sterczeć. Co dziś będziesz robić w domu?

- Ja dzisiaj idę do szkoły, dziadku! - odpowiedział Ago. Wsiadł na osła i odjechał (2012, s. 28-29).

Dalej autor opisuje siew oziminy. Vosgehan zakłada wołom jarzmo, przynosi pozostawiony na miedzy pług - w tej wsi narzędzia zostawia się na noc w polu, bo nie ma tutaj złodziei. Najpierw dwukrotnie obsiewa kawałek pola, chodząc z góry na dół i w poprzek zbocza. Potem przyoruje zasiany zagon, cały czas łagodnie przemawiając do wołów. Kiedy one 
odpoczywają, on obsiewa następną część pola. Praca to ciężka, ale Vosgehan wykonuje ją z radością. Jak okiem sięgnąć, na okolicznych zboczach wieśniacy obsiewają swoje zagony. W południe Vosgehan przerywa siew, podobnie jak wszyscy inni wokół. Pora na posiłek. Woły dostają po wiązce pachnącego ziołami siana, a gospodarz przelewa zupę ajranową z glinianego garnka obwiązanego skórzaną pokrywką do miedzianej miski. Wrzuca do zupy kawałki chleba i zagryzając cebulą, je za pomocą wielkiej drewnianej łyżki. Obok pola Vosgehana przechodzą cztery młode kobiety z łopatami i wojłokowymi workami. Idą na Gliniane Wzgórze po glinkę. W każdej wsi jest takie miejsce, gdzie można znaleźć pokłady glinki nadającej się do opieki nad niemowlęciem. Wszak to epoka, kiedy anatolijska kobieta nie słyszała jeszcze o pieluchach. Zgromadzenie odpowiedniej ilości glinki jest zadaniem każdej ciężarnej kobiety, a spore zapasy trzeba też zrobić przed nadejściem zimy, aby starczyło aż do wiosny.

- Niech wam Bóg da dużo siły, wuju Vosgehanie! Tobie i twoim wołom! - zawołała Haszman.

- Coś późno idziecie kopać! - odpowiedział Vosgehan. - Moje synowe już dwie niedziele temu zrobiły zapasy.

- Nie, jeszcze nie jest za późno! - odparła. - My też zaraz sobie uzbieramy (2012, s. 31).

Zaspokoiwszy głód, gospodarz i jego woły powracają do pracy. Po obsianiu i zaoraniu całego zagonu Vosgehan odpina od jarzma pług, zastępując go lekką broną. To już ostatnia przewidziana na ten pracowity dzień robota, lekka, radosna i przyjemna: wyrównanie całego obsianego pola. Na koniec cały zagon wygląda jak jednolita, nieskazitelna płaszczyzna. Vosgehan układa na miedzy jarzmo, pług i bronę, mówiąc do wołów, choć pewnie bardziej do siebie, że jutro przyjdą tu znów, aby pomóc w pracy na polu sąsiada. Wciąż jeszcze jest jasno, ale słońce już zaszło, wszystkie pola i zbocza zakrył cień, a na niebie pojawiła się pierwsza gwiazdka. Woły, uwolnione od jarzma, natychmiast ruszają przed siebie dostojnym krokiem. Podobnie jak rano, zatrzymują się przy wodopoju i długo piją. Gdy wchodzą do stajni, młodsza synowa właśnie roznosi siano do żłobów.

Dookoła pachniało sianem. Woły skierowały się prosto na swoje legowiska i zaczęły jeść.

- Ja idę do domu. Jutro biały wół zostanie odpoczywać, a ciebie zabieram w pole - powiedział Vosgehan do trzeciego wołu, dotykając go lekko.

Wszedł do domu, zdjął łapcie i skierował się do pokoju. (...) Połowę podłogi zajmowała czarna kapa z koziej wełny. Gasmaly, żona Vosgehana, usadowiła dookoła niej pięcioro wnucząt. Byli to: Toro, Ago, Sero, Vosgeg i Szuszanig. Najmniejsza była Szuszanig - miała trzy lata. Wszystkie 
dzieci usiadły karnie z nogami podwiniętymi, nikt nie wyciągał nóg przed siebie. A najgrzeczniej siedziała Szuszanig. Króciutkie poły swojej sukienki podłożyła pod kolana. Babcia położyła przed każdym dzieckiem chleb, dała każdemu łyżkę. W największej misie przyniosła zupę sermug z drobnej kaszy. W tym domu nie było grymaszenia: „ja tego nie będę jeść”. Dzieci podrobiły chleb i wrzuciły do misy, aż wypełniła się po brzeg. I machając łyżkami, zjadły wszystko do dna (2012, s. 35).

Po zupie gospodyni przynosi na patelni drugą potrawę zwaną szurwa. Jest to rodzaj jajecznicy wylanej na przysmażoną z mąką cebulę. To danie również spożywane jest z dużą ilością chleba, który rwie się na małe kawałki, zanurza w patelni i nabiera do ust. Po posiłku dzieci kładą się spać. Synowe wracają ze stajni i dorośli zasiadają do kolacji - takiej samej, jaką miały dzieci. Usługuje młodsza synowa. Podaje posiłek, siada ze wszystkimi i je, potem sprząta i zmywa naczynia. Opowiadanie kończy się ulubionym przez Mintzuriego zabiegiem retorycznym, jakim jest żartobliwa personifikacja. Tym razem w roli głównej występują wrony.

$\mathrm{Z}$ orzecha rosnącego u sąsiada dochodziły niekończące się wrzaski wron. Znowu się zebrały. Znowu zaczęły posiedzenie. Podzieliły się na dwie frakcje i zaczęły do siebie gardłować: kra-kra, kra-kra. Ich kierowniczki, które usadowiły się na najwyższej gałęzi, na próżno usiłowały w swoim wronim języku zmusić je do milczenia. W domu wszyscy już się położyli, a wrzaskliwa dyskusja wron trwała aż do świtu (2012, s. 36).

W opowiadaniu Jesień udało się autorowi zawrzeć najważniejsze rysy wschodnioanatolijskiej rodziny ormiańskiej i jej świata. Podobne obrazy można znaleźć w innych jego opowiadaniach, ale także we wspomnieniach (2002a), co może wskazywać na autobiograficzne uwarunkowania nowelistyki Mintzuriego. Oto najbardziej charakterystyczne cechy unicestwionego w 1915 roku świata Ormian anatolijskich:

- Rodziny są liczne, wielodzietne, głową domu jest starszy mężczyzna. Ważne miejsce zajmuje żona gospodarza, która jest w hierarchii drugą po nim osobą. Synowe są ciche, potulne, bardzo ciężko pracują w domu, w stajni i na polu. Zaawansowana ciąża nie zwalnia z pracy. Jak wielki wkład w dobrobyt rodziny mają synowe, pokazuje opowiadanie Stambut, w którym opisana jest podróż młodej kobiety do męża od czterech lat pracującego w Stambule. Stęskniony, pisze list do ojca i prosi, aby ten przysłał mu jego żonę. Sprawa nie jest prosta, bo każde ręce zdolne do pracy są w tym domu na wagę złota. W końcu synowi udaje się przekonać ojca do zatrudnienia pracownika do pomocy w polu i młoda żona wyrusza w długą drogę do męża. A znamienne 
są słowa ojca, który na początku sprzeciwia się pomysłowi syna, pisząc do niego w liście:

No dobrze, Awedisie, ale co my tutaj poczniemy? Jak sobie poradzimy $\mathrm{z}$ robotą? Twoja matka i ja martwimy się o to. Młodsza synowa Taro zostanie sama. Nawet jak są dwie, to $\mathrm{z}$ trudem nadążają z robotą, a co będzie, jak poślemy Tyszchu do ciebie? Wiesz przecież, ile mamy pola tu na równinie i w górach, ile ogrodów mamy we wsi, ile winnic nad rzeką. To wszystko potrzebuje człowieka. Owszem, twój brat Toros orze, sieje, młóci; przywiezie z gór opał. Ale jak obrobimy tyle pól jedną synową? No tak, są dzieci, chłopaki, dziewczęta, ale ileż można z ich pomocą zrobić? Bywa i tak, że w tym samym dniu wypada na nas kolej z podlewaniem i ogrodów, i winnic. To jak jedna synowa ma z tym nadążyć? Jeśli nie wykorzystamy swojej kolejki, to przepadnie. (...) A morwy? Kto to zbierze, rozłoży, wysuszy? A siano? Ile siana może zebrać jedna synowa? A przecież stodołę trzeba zapełnić, żeby woły, krowy i owce miały co jeść w zimie. Pewnie, że można dzieci posłać do siana, ale ile one tego mogą skosić? No, powiedz... (2012, s. 35-36).

- Opiekę nad dziećmi sprawuje babcia. Ona też przygotowuje posiłki. Synowe - zajęte pracą w polu - nieraz nie widują dzieci przez cały dzień. Jedno z opowiadań, zatytułowane Nasze matki, jest pięknym hołdem autora złożonym ormiańskim matkom. Opisuje ich pozbawione radości życie i ciężką pracę wykonywaną bez słowa sprzeciwu. Oprócz matek głównymi bohaterami w tym opowiadaniu są teściowe:

My, dzieci, nie mówiliśmy na nasze matki „mayr” ani „mayrig” [orm. „matka”, „mamusia” - G.Z.]. Nikt nas tego nie nauczył. Nie znaliśmy tego. Mówiliśmy „harsig”. W naszym regionie to nie było zdrobnienie słowa „hars” [orm. „synowa” - G.Z.), tylko oznaczało matkę. Języka uczyliśmy się od naszych babć. Ponieważ na nasze matki wołały „harsig”, to i nas do tego przyzwyczajały. (...) Byliśmy wychowywani przez babcie. Powinnością naszych matek było karmić nas do momentu odstawienia od piersi. Wpadały na chwilę, karmiły, potem nagle wyjmowały nam pierś z ust i natychmiast odchodziły. Pomyślałbyś, że to ktoś obcy.

To nasze babcie wszystko koło nas robiły. Rano wyjmowały z kołyski, przebierały; jeśli już nie byliśmy dziećmi przy piersi, to nas karmiły, a jeśli jeszcze ssaliśmy, to wołały nasze matki. W kołysce kładły nas na drobno przesianym piasku. Gdy go zmoczyliśmy, wyjmowały to, co mokre, a dokładały suchego. Gdy zmoczyliśmy powijaki, dawały naszym matkom, aby poszły wyprać w korycie przy wiejskiej studni. To babcie nas myły, czesały, szyły nam koszule i portki, łatały nasze ubranka (2012, s. 67-68).

Ta sytuacja i tak nie była jeszcze całkiem zła dla dzieci, bo babcie dbały o wszystkie ich potrzeby. Dotyczyło to jednak okresu zimowego 
oraz dzieci starszych niż dwuletnie (praktykowano karmienie piersią do ukończenia dwóch lat). W innych porach roku, kiedy na polach było dużo pracy, dzieci będące jeszcze przy piersi spędzały cały dzień z matkami daleko poza wsią i było to trudne tak dla matek, jak i niemowląt. Jak pisze Mintzuri w opowiadaniu $M y-d z i e c i$ poświęconym wyłącznie dzieciom i dzieciństwu, matki szły do pracy z niemowlętami na plecach. Na miejscu wkładały dzieci do prymitywnych hamaków rozwieszonych między drzewami, a gdy pracowało się w polu pozbawionym drzew, kładły becik na ziemi, w cieniu skał. Dzieci nieraz bardzo długo płakały, zanim matka mogła oderwać się od pracy (2012, s. 134-135).

- Synowe spędzają długie miesiące i lata bez swoich mężów, którzy wyjeżdżają do pracy. Ten aspekt życia wiejskich kobiet jest bardzo przygnębiający. Dopóki same nie zostaną teściowymi, są „tylko” synowymi w domu teściów, a jeśli nawet wyszły za mąż z miłości, nie jest im dane tą miłością się cieszyć:

Nasze matki były po to, aby rodzić „bylig” [orm. „dziecko” - G.Z.] i jeszcze po to, aby i w domu, i poza domem wykonywać ciężkie prace. Po to brano je za żony dla naszych ojców. Ale ani nasi ojcowie nie byli szczęśliwi, ani nasze matki. Szczególnie - one. Rok po ślubie nasi ojcowie zostawiali je we wsi i wyjeżdżali za chlebem. Większość z nas jeszcze nie zdążyła się urodzić, albo mieliśmy najwyżej 1-2 miesiące. I ten pobyt na obczyźnie trwał nieraz całe życie. Raz na 4-5 lat przyjeżdżali do wsi, spędzali tu rok i znowu odjeżdżali. Od wieku dwudziestu do sześćdziesięciu lat, czyli w ciągu czterdziestu lat życia, przebywali we wsi wszystkiego pięć, a najwyżej dziesięć lat. A nasze matki przez trzydzieści-czterdzieści lat żyły jak wdowy (2012, s. 71).

Autor docenia poświęcenie ormiańskich matek i dostrzega zło, jakie je dotykało. Opowiada o nich zwrotami pełnymi miłości i współczucia, a utwór Nasze matki kończy tymi dojmującymi słowami: „I takie oto są historie naszych matek. To, co one wycierpiały, nie było nawet udziałem świętych dziewic. Nawet nasze męczennice jak Gajana czy Rypsyma ${ }^{6}$ nie były aż tak udręczone” (2012, s. 73).

- Warunki życia i pracy w ormiańskich wioskach Anatolii są bardzo ciężkie, co wynika z ukształtowania terenu. Wioski leżą w dolinach, w miejscach $z$ dostępem do wody (często jest to jedno ujęcie wody na

6 Mowa tu o grupie 37 chrześcijańskich mniszek straconych w 301 r. przez króla Armenii Tiridatesa III w Eczmiadzynie. Wśród nich znajdowały się: Gajana, przywódczyni świętych kobiet, oraz Rypsyma, torturowana za to, że nie chciała oddać się królowi. 
całą miejscowość), i są gęsto zabudowane domami mieszkalnymi, stajniami i stodołami. Dlatego we wsi nie ma już miejsca - poza małymi ogrodami - na uprawy. W rodzinnej wsi autora na pola uprawne i pastwiska szło się godzinę - półtorej godziny (2012, s. 134).

- Trudne warunki geograficzne wymuszają na całej społeczności wspólne działanie i wzajemną pomoc. W okresie natężenia prac polowych, szczególnie podczas zbiorów, kilka rodzin pracuje razem na jednym polu, kolejno u każdego gospodarza. Mężczyźni wspólnie dokonują wiosennej i jesiennej orki, a kobiety razem pracują przy zbiorach. W opowiadaniu $M y-d z i e c i$ autor pisze:

W sierpniu, w czasie żniw, nie było chodzenia z domu w pole i z powrotem, tylko trzy-cztery domy umawiały się i razem wyruszano na cały miesiąc w góry, w dwadzieścia osób lub więcej. Spało się w górach. Stawiano dla nas namiot na trzech tyczkach i wszystkie niemowlęta kładziono tam razem. Gdy dziecko się obudziło, matka zaraz przychodziła. Ale to nie znaczy, że ssaliśmy tylko własne matki! (...) Jeśli nie było w pobliżu Ormianki, to brała nas do karmienia Turczynka, Kurdyjka czy alewitka. Chętnie to robiły. Bały się Boga. Gdyby się ociągały z taką pomocą, Bóg mógłby się rozgniewać i zesłać na kobietę karę. A mnie podobno raz nawet nakarmiła Cyganka. Gdy już byłem większy i zdarzało mi się późno wrócić do domu, mama albo babcia mówiły: „Cóż się dziwić! Piłeś cygańskie mleko, to teraz się włóczysz” (2012, s. 135-136).

W opowiadaniu Winnice Armudanu Mintzuri szczegółowo kreśli obraz ciężkiej pracy Ormian anatolijskich: w potwornym upale, wśród tak donośnego odgłosu cykad, że okresowo traciło się słuch, i w ciagłym niebezpieczeństwie natknięcia się na jadowite żmije, których ukąszenie oznaczało niechybną śmierć. A na koniec tego smutnego opowiadania autor dodaje:

Ale muszę jeszcze i to powiedzieć, że te nasze plony nie miały wielkiej wartości. Nie było rynku zbytu. Nie było chętnych do zakupu. Dlatego sami siebie wystawialiśmy na sprzedaż. Aby zdobyć trochę pieniędzy dla domu, wyruszaliśmy na obczyznę: do Stambułu, Warny, Bukaresztu, Odessy... (2012, s. 181).

\section{Zakończenie}

„Moje utwory to moja biografia. We wszystkim, co opowiadam, co mówię, można mnie znaleźć, bo ja tam byłem, żyłem tam” - tak Hagop Mintzuri mówił w roku 1966 o swojej twórczości, przygotowując do druku tom 
opowiadań (za: Mintzuri, 2002b, s. 143). Doniosłe znaczenie dokumentalne Mintzuriego bierze się właśnie stąd, że fabuła jego nowel oparta jest na wspomnieniach. Nie bez powodu utwory o charakterze wspomnieniowym, jak autobiografie, pamiętniki, dzienniki, listy określa się mianem „literatury dokumentu osobistego”. Kluczowe w tej nazwie słowo „dokument” zdaje się przybliżać literaturę wspomnieniową do nowelistyki Mintzuriego. O dokumentalnej wartości swoich opowiadań mówił też wtedy Mintzuri tymi słowami:

W historii literatury moja sytuacja jest wyjątkowa: opowiadam o miejscach, w których nie ma już moich bohaterów ani ich potomków. Moje opowieści to nie tylko zwykłe opowieści, ale i folklor regionu, gdzie niegdyś żyli moi bohaterowie, a także historia narodu. Pisząc, daję świadectwo. Gdy piszę, tworzę film, tworzę teatr o tych ludziach. To jest panteon, który przemieniam w dzieło literackie (za: Mintzuri, 2000, s. 9).

Jakże to gorzkie słowa! Jak wielki ból musiał trawić serce tego człowieka, który „przez przypadek” zachował życie, gdy stracili je w nieznanych okolicznościach i w nieznanym miejscu wszyscy jego najbliżsi. Zapewne ta rozpacz spowodowała, że po pierwszych próbach literackich między 1906 a 1914 r. zamilkł na długie lata. A kiedy zaczął pisać na nowo, stworzył niepowtarzalny i bardzo autentyczny (bo czerpiący ze wspomnień) obraz utraconej ojczyzny wraz z jej mieszkańcami, radościami, smutkami, folklorem i wszystkim tym, co składa się na ludzkie życie. Przechowywany w pamięci przez długie lata obraz utraconego narodu i utraconej ojczyzny przelał na papier, pozostawiając potomnym swoisty „panteon” i oddając hołd unicestwionym.

\section{BiBLIOGRAFIA}

Genç, G.A. (2013). İstanbul sürgünü Armıdanlı Hagop. Agos, 25.05.2013. Pozyskano z: http://www.agos.com.tr/tr/yazi/5043/istanbul-surgunu-armidanli-hagop (dostęp: 14.02.2021).

Kucharczyk, G. (2004). Pierwszy holocaust XX wieku. Warszawa: Fronda.

Lewis, B. (1972). Narodziny nowoczesnej Turcji. Warszawa: PWN.

Mintzuri, H. (2000). Atina, Tuzun Var Mi? Tłum. S. Kuyumcuyan. İstanbul: Aras.

Mintzuri, H. (2002a). İstanbul Anıları. Tłum. S. Kuyumcuyan. İstanbul: Tarih Vakfi Yurt Yayınları.

Mintzuri, H. (2002b). Kapandı Kirve Kapıları. Tłum. N. Büyükkürkciyan. İstanbul: Aras. 
Mintzuri, H. (2012). Turna Nereden Gelirsin. Tłum. S. Kuyumcuyan. İstanbul: Aras.

Riedler, F. (2009). Hagop Mintzuri and the Cosmopolitan Memory of Istanbul, San Domenico di Fiesole, 2009. Pozyskano z: https:// cadmus.eui.eu/bitstream/handle/1814/10913/EUI_RSCAS_2009_13. pdf? sequence $=1$ \&isAllowed $=\mathrm{y}($ dostęp: 14.02 .2021$)$.

Wituch, T. (1980). Tureckie przemiany. Dzieje Turcji 1878-1923. Warszawa: PWN.

Zając, G. (2008). Smutna ojczyzna i ja smutny... Kręgi literackie epoki Abdülhamita II w świetle tureckiej autobiografii. Kraków: Księgarnia Akademicka.

Zając, G. (2013). Ciato twoje, kości moje. Rodzina i szkota epoki Abdülhamita II $w$ świetle tureckiej autobiografii. Kraków: Księgarnia Akademicka.

Zając, G. (2016). Szkolnictwo chrześcijańskie XIX-wiecznej Turcji i jego obraz w tureckiej autobiografii. W: D. Quirini-Popławska i Ł. Burkiewicz (red.), Sacrum w mieście (t. 2). Kraków: Wydawnictwo WAM, 205-220.

Zając, G. (2020). Halit Ziya Uşaklıgil - turecki wychowanek katolickiej szkoły ojców mechitarystów. Nurt SVD, nr 2/2020, 198-212.

Grażyna Zając - orientalista-turkolog, prof. nadzw. UJ. Specjalizuje się w badaniach nad literaturą turecką XIX i XX w., ze szczególnym uwzględnieniem autobiografii oraz literatury Turków cypryjskich. Tłumaczy literaturę turecką, współpracuje z redakcjami czasopism polskich Tatarów „Przegląd Tatarski” i „Rocznik Tatarów Polskich”. Ważniejsze publikacje: Smutna ojczyzna i ja smutny... Kręgi literackie epoki Abdülhamita II w swietle tureckiej autobiografii (2008); Ciato twoje, kości moje. Rodzina i szkota epoki Abdülhamita II w świetle tureckiej autobiografii (2013). 